The Hour of Europe 
This page intentionally left blank 


\title{
The Hour OF
} EUROPE

Western Powers and the Breakup of Yugoslavia

\author{
Josip Glaurdić
}

Yale

UNIVERSITY PRESS

New Haven E London 
Published with assistance from the Louis Stern Memorial Fund.

Copyright (C) 2011 by Josip Glaurdić.

All rights reserved.

This book may not be reproduced, in whole or in part, including illustrations, in any form (beyond that copying permitted by Sections 107 and 108 of the U.S. Copyright Law and except by reviewers for the public press), without written permission from the publishers.

Yale University Press books may be purchased in quantity for educational, business, or promotional use. For information, please e-mail sales.press@yale.edu (U.S.office) or sales@yaleup.co.uk (U.K. office).

Set in Electra type by IDS Infotech Ltd., Chandigarh, India. Printed in the United States of America.

Library of Congress Cataloging-in-Publication Data

Glaurdić, Josip, 1979-

The hour of Europe : Western powers and the breakup of Yugoslavia / Josip Glaurdić. p. cm.

Includes bibliographical references and index.

ISBN 978-0-300-16629-3 (cloth : alk. paper) 1. Yugoslavia-Politics and government-1980-1992. 2. Yugoslavia-History-1980-1992. 3. YugoslaviaForeign relations-1980-1992. 4. Cold War. 5. Europe, Western-Relations-

Yugoslavia. 6. Yugoslavia-Relations-Europe, Western. 7. Yugoslav War, 1991-1995-Causes. 8. Yugoslav War, 1991-1995. 9. Europe, Western-Politics and government-1989- I. Title.

$$
\begin{gathered}
\mathrm{DR}_{13} 09 \cdot \mathrm{G}_{55} 2011 \\
949.703-\mathrm{dc}_{22}
\end{gathered}
$$

A catalogue record for this book is available from the British Library.

This paper meets the requirements of ANSI/NISO Z39.48-1992 (Permanence of Paper). 
For Sandra 
This page intentionally left blank 